\title{
7: 41513299-41502036
}

National Cancer Institute

\section{Source}

National Cancer Institute. 7: 41513299-41502036. NCI Thesaurus. Code C45138.

Physical location of INHBA_Gene 